\title{
Coxsackie and adenovirus receptor is a target and a mediator of estrogen action in breast cancer
}

\author{
David Vindrieux ${ }^{1,2}$, Ludovic Le Corre ${ }^{1,2}$, Jer-Tsong Hsieh ${ }^{3}$, \\ Raphaël Métivier ${ }^{4}$, Pauline Escobar ${ }^{1,2}$, Andrès Caicedo ${ }^{1,2}$, \\ Madly Brigitte ${ }^{1,2}$ and Gwendal Lazennec ${ }^{1,2}$
}

\author{
${ }^{1}$ INSERM, U844, Hôpital Saint Eloi, Montpellier F-34091, France \\ ${ }^{2}$ University of Montpellier I, Montpellier F-34090, France \\ ${ }^{3}$ Department of Urology, University of Texas Southwestern Medical Center, 5323 Harry Hines Boulevard, Dallas, Texas 75390-9110, \\ USA \\ ${ }^{4}$ Université de Rennes I, CNRS, UMR 6026 Equipe SPARTE, Rennes F-35042, France \\ (Correspondence should be addressed to G Lazennec, INSERM, U844, Site Saint Eloi, Bat. INM, 80, rue Augustin Fliche, 34295 \\ Montpellier, France; Email: gwendal.lazennec@inserm.fr)
}

\begin{abstract}
The involvement of the coxsackie and adenovirus receptor $(C A R)$, an adhesion molecule known to be the main determinant of adenovirus transduction of the cells, in cancer is currently under investigation. Recent reports suggest that $C A R$ levels are elevated in breast cancer, and this may have an impact on its use as means of delivery for gene therapy. In this study, we show that estradiol $\left(E_{2}\right)$ treatment of the estrogen receptor (ER)-positive breast cancer cell MCF-7 increases $C A R$ levels and, in turn, enhances adenoviral transduction. Employing the transfection of $C A R$ promoters in breast cancer cells, we show that this regulation of $C A R$ expression occurs at the transcriptional level. In addition, and by chromatin immunoprecipitation, we have identified a crucial region of $C A R$ promoter that controls $\mathrm{E}_{2}$ responsiveness of $C A R$ gene through the recruitment of ER. Moreover, utilizing $C A R$ antibodies or CAR silencing by RNA interference repressed the estrogen-dependent growth of breast cancer cells, whereas the stable expression of CAR in MCF-7 or MDA-MB-231 cells led to an increased proliferation. Altogether, our data suggest that $C A R$ is a novel estrogen-responsive gene, which is involved in the $\mathrm{E}_{2}$-dependent proliferation of breast cancer cells.
\end{abstract}

Endocrine-Related Cancer (2011) 18 311-321

\section{Introduction}

The coxsackie and adenovirus receptor $(C A R)$ is a transmembrane protein that was initially characterized by its ability to allow adenovirus attachment through cells via the interaction with the adenovirus fiber-knob protein (Bergelson et al. 1997, Lucas et al. 2003, Glasgow et al. 2006). Splice variants of $C A R$ have also been identified, which could generate soluble forms of the $C A R$ protein that lack a transmembrane domain (exon 6) (Thoelen et al. 2001). In normal cells, CAR is associated with tight junctions (TJs) protein complexes (Cohen et al. 2001). CAR has recently been suspected to be involved in cancer development, but its role remains controversial. Several studies have shown that $C A R$ expression was reduced in cancer tissues compared with normal tissues in the case of bladder, renal, and prostate cancers (Li et al. 1999, Okegawa et al. 2000, Okegawa et al. 2001, Haviv et al. 2002, Sachs et al. 2002, Matsumoto et al. 2005), whereas in the breast, CAR expression is increased in tumors (Martin et al. 2005). The loss of $C A R$ expression is also associated with increased metastasis of bladder tumors (Matsumoto et al. 2005).

So far, very little is known about $C A R$ expression in breast cancer biopsy, and the situation appears to be significantly different from other cancers. A study showed that $C A R$ levels are elevated in breast cancer and increase during progression and metastasis (Martin et al. 2005). In addition, CAR expression is correlated to estrogen receptor (ER) expression in breast cancer 
cells (Auer et al. 2009). Estrogens are potent mitogens in cancerous breast tissue (Henderson et al. 1988, Lazennec et al. 1999, Katzenellenbogen et al. 2000). Studies in breast cancer tissue, both in vivo and in vitro, have shown that estrogen dramatically escalates proliferative and metastatic activity in these tumor cells. The growth of $\sim 70 \%$ of all human breast cancers is dependent upon the presence of an estradiol $\left(\mathrm{E}_{2}\right)$-ER complex (Santen et al. 1990). The genomic action of estrogen is mediated by two ERs, namely ER $\alpha$ and $\mathrm{ER} \beta$ (Katzenellenbogen et al. 2000). ER $\alpha$ is mainly involved in the mitogenic action of estrogens, whereas $\mathrm{ER} \beta$ is rather anti-proliferative both in breast, prostate, and ovarian cancer (Lazennec et al. 2001, Bardin et al. 2004, Cheng et al. 2004, Lazennec 2006).

The aim of this study was to analyze the link between $C A R$ and estrogen signaling in breast cancer and to determine the possible role of $C A R$ in breast cancer and the mechanisms of regulation of $C A R$ by estrogens. We report that the treatment of ER-positive breast cancer cells leads to an increased transduction by adenovirus, which is concomitant with an induction of $C A R$ mRNA and protein levels. The analysis of the $C A R$ promoter revealed that $C A R$ regulation by estrogens occurs at the transcriptional level, through an estrogen-responsive element (ERE). Very interestingly, the blockage of $C A R$ action was sufficient to reduce the estrogen-dependent proliferation of breast cancer cells, whereas the ectopic expression of $C A R$ could increase the proliferation of breast cancer cells.

\section{Materials and methods}

\section{Cell culture}

MCF-7 and MDA-MB-231 cells were maintained in DMEM-F12 and supplemented with 10\% FCS and gentamycin as described previously (Lazennec et al. 1996). For infection assays, cells were seeded on 6-well plates. Before any experiment, cells were weaned off steroids by being cultured in phenol redfree DMEM/F12 that had been supplemented with $10 \%$ charcoal dextran-treated FCS (CDFCS) for 5 days.

\section{RNA extraction and reverse transcriptase PCR}

Total RNA was isolated with TRIzol reagent (Invitrogen) as described by the manufacturer. Reverse transcription was performed using random primers and Superscript II enzyme (Invitrogen). Real-time PCR quantification was then performed using a SYBR Green approach (Light Cycler; Roche), as described previously (Lucas et al. 2003). For each sample, CAR or pS2/TFF1 mRNA levels were normalized with $R S 9$ or
RplpO mRNA levels (reference genes). The sequences of the oligonucleotides used were $C A R$ (transmembrane CAR, exons 6/7, (Thoelen et al. 2001)) (left 5'-GCAGGAGCCATTATAGGAACTTTG-3'; right 5'-GGACCCCAGGGATGAATGAT-3'), pS2/TFF1 (left $5^{\prime}$ ACCATGGAGAACAAGGTGA- $3^{\prime}$; right $5^{\prime}$-CCGAGCTCTGGGACTAATCA-3'), RS9 (left $5^{\prime}$-CAGGCGCAGACGGTGGAAGC-3'; right $5^{\prime}$-CGCGAGCGTGGTGGATGGAC-3'), Rplp0 (left 5'-AAYGTGGGCTCCAAGCAGATG- $3^{\prime}$; right $5^{\prime}$-GAGATGTTCAGCATGTTCAGCAG-3' ${ }^{\prime}$ ).

\section{Recombinant adenovirus construction, propagation, and infection}

The adenoviruses encoding the $\beta$-galactosidase (Ad-GAL) or ER $\alpha$ (Ad-ER $\alpha$ ) used in this study have been previously described (Lazennec et al. 1999, 2001, Lucas et al. 2003). Briefly, the complete coding sequences of $\beta$-galactosidase, or human $\mathrm{ER} \alpha \mathrm{cDNAs}$, were subcloned in a pACsk12CMV5 shuttle vector. To obtain recombinant viruses, permissive HEK-293 cells (human embryonic kidney cells) were cotransfected with pACsk12CMV5, or the recombinant pACsk12CMV5 plasmid, and with pJM17 that contains the remainder of the adenoviral genome. In vivo recombination of the plasmids generates infectious viral particles, non-recombinant adenovirus Ad5, or recombinant adenovirus Ad-GAL and Ad-ER $\alpha$. MCF-7 or MDA-MB-231 cells were infected overnight at different multiplicities of infection (MOI) in DMEM/F12 10\% CDFCS. The next day, the medium was changed and the cells were let to express $\beta$-GAL for $48 \mathrm{~h}$ before collecting the medium.

\section{$\beta$-Galactosidase histochemical staining assay}

After $48 \mathrm{~h}$ of expression, infected cells were washed twice with PBS and then fixed for $5 \mathrm{~min}$ at $4{ }^{\circ} \mathrm{C}$ in a fixing solution (2\% formaldehyde, $0.2 \%$ glutaraldehyde, and $1 \times \mathrm{PBS})$. Cells were washed once and incubated for $4 \mathrm{~h}$ at $37^{\circ} \mathrm{C}$ in histochemical staining solution $\left(5 \mathrm{mM} \mathrm{K}_{3} \mathrm{Fe}(\mathrm{CN})_{6}, 5 \mathrm{mM} \mathrm{K} \mathrm{K}_{4} \mathrm{Fe}(\mathrm{CN})_{6}, 2 \mathrm{mM}\right.$ $\mathrm{MgCl}_{2}, 1 \times \mathrm{PBS}$, and $1 \mathrm{mg} / \mathrm{ml} \mathrm{X}-\mathrm{GAL}$; Lucas et al. 2003). Cells were then washed twice with PBS and observed.

\section{Western blot experiments}

Cells were harvested in Tris-glycerol buffer (Tris- $\mathrm{HCl}$ $50 \mathrm{mM}$, EDTA $1.5 \mathrm{mM}$, and $10 \%$ glycerol) supplemented with protease inhibitor cocktail (Roche) and were then sonicated. Protein extracts $(30 \mu \mathrm{g})$ were subjected to SDS-PAGE protein samples under 
non-reducing conditions. Samples were heated normally at $95^{\circ} \mathrm{C}$ for $5 \mathrm{~min}$ in a sample loading buffer that lacked mercaptoethanol. Western blot analyses were done using CAR antibody (sc-56892, Santa Cruz, CA, USA) and $\beta$-actin (Sigma-Aldrich). Immunoreactivity was detected with Amersham ECL system. Actin was used as a loading control.

\section{Constructs and transient transfection}

A CAR promoter corresponding to sequences -1213/-127 (pGL3-1087) has been previously described (Pong et al. 2003). Deleted constructs of the $C A R$ promoter (pGL3522: -648/-127; pGL3-428: -554/-127) were cloned into pGL3 basic vectors (Promega). Site-directed mutagenesis of $C A R$ ERE was performed with CAR-EREm primers (TCGCATCCCGTGgGCATGtcGTCAGAGAACCTGCC) to generate pGL3-EREm construct. The ERE-TK-LUC construct consists of two ERE in tandem upstream of TK promoters (Duong et al. 2006). We plated $3.10^{5}$ of steroid-weaned cells in 12-well plates in phenol red-free DMEM-F12 and supplemented with $10 \%$ CDFCS $24 \mathrm{~h}$ before transfection. Transfections were performed using lipofectamine according to the manufacturer's recommendations, using $2 \mu \mathrm{g}$ of the $C A R$ promoter pGL3-1087, luciferase reporter, or $C A R$ promoted deleted constructs along $0.5 \mu \mathrm{g}$ of the internal reference reporter plasmid (CMV-Gal) per well. After $6 \mathrm{~h}$ incubation, the medium was removed and the cells were placed into a fresh medium supplemented with a control vehicle (ethanol) or $E_{2}$. After $24 \mathrm{~h}$, cells were harvested and assayed for luciferase activity using a Centro LB960 Berthold luminometer. $\beta$-galactosidase was determined as described previously (Duong et al. 2006).

\section{siRNA experiments}

$C A R$ protein was knocked down by transfection of MCF-7 cells with specific siRNA (GGAAGUUCAUCACGAUAUAUC, Eurofins) according to manufacturer's protocol. Non-targeting control siRNA (siGLO red) was purchased from Dharmacon. Protein levels were determined by western blot.

\section{CAR stable transfectants}

The stably transfected MCF-7-CAR and MDA-MB231-CAR cell lines were obtained after transfection with the plasmid pcDNA3-hCAR (a kind gift of Dr $\mathrm{S}$ Hemmi), encoding the human $C A R$ cDNA under the control of the CMV promoter. Transfected cells were then selected by G418 at a concentration of $2 \mathrm{mg} / \mathrm{ml}$. After 2 weeks of selection, a pool of resistant cells was collected and used for further experiments.

\section{Chromatin immunoprecipitations}

These assays were conducted with some modifications from Métivier et al. (2003), using $1.10^{7} \mathrm{MCF}-7$ or MDA-MB-231 cells that were placed in DMEM/0.5\% CDFCS for 3 days. Afterward, some were treated with $10 \mathrm{nM} \mathrm{E}_{2}$ four different times. Following cross-linking ( $1.5 \%$ formaldehyde for $10 \mathrm{~min}$ at room temperature), cells were collected in a $1 \mathrm{ml}$ collection buffer (100 mM Tris- $\mathrm{HCl}(\mathrm{pH} 9.4)$ and $100 \mathrm{mM}$ dithiothreitol), and incubated on ice for $10 \mathrm{~min}$ and subsequently at $30^{\circ} \mathrm{C}$ for $10 \mathrm{~min}$. Cells were then lysed in a $300 \mu \mathrm{l}$ lysis buffer (10 mM EDTA, $50 \mathrm{mM}$ Tris- $\mathrm{HCl}$ (pH 8.0), $1 \%$ SDS, and $0.5 \%$ Empigen BB (Sigma)). Extracts were then sonicated for $14 \mathrm{~min}$ using a BioRuptor apparatus (Diagenode), with $30 \mathrm{~s}$ on/off cycles. Following $10 \mathrm{~min}$ centrifugation at $10000 \mathrm{~g}, 50 \mu \mathrm{l}$ of the supernatants were used as inputs, and the remainder diluted threefold in IP buffer ( $2 \mathrm{mM}$ EDTA, $100 \mathrm{mM}$ $\mathrm{NaCl}, 20 \mathrm{mM}$ Tris- $\mathrm{HCl}(\mathrm{pH} 8.1$ ), and $0.5 \%$ Triton $\mathrm{X}-100)$. Extracts were pre-cleared for $3 \mathrm{~h}$ at $4{ }^{\circ} \mathrm{C}$ with $150 \mu \mathrm{l}$ of a $50 \%$ protein A-Sepharose bead (Amersham Pharmacia Biosciences) slurry containing $10 \mu \mathrm{g}$ yeast tRNA (Sigma). Following centrifugation at $800 \mathrm{~g}$ for $1 \mathrm{~min}$, one-third of the extracts were taken for immunoprecipitation using $1 \mu \mathrm{g}$ of antibodies directed against ER (HC20, Santa Cruz) or the epitope HA (HA-probe Y11, Santa Cruz) and diluted three times in a IP buffer. Complexes were recovered by a $3 \mathrm{~h}$ incubation at $4{ }^{\circ} \mathrm{C}$ with $50 \mu \mathrm{l}$ of protein A-Sepharose slurry containing $10 \mu \mathrm{g}$ yeast tRNA. Precipitates were then serially washed, using $300 \mu \mathrm{l}$ of washing buffers (WB) I (2 mM EDTA, 20 mM Tris- $\mathrm{HCl}$ (pH 8.1), $0.1 \%$ SDS, $1 \%$ Triton $\mathrm{X}-100$, and $150 \mathrm{mM} \mathrm{NaCl}$ ), WB II ( $2 \mathrm{mM}$ EDTA, $20 \mathrm{mM}$ Tris-HCl (pH 8.1), $0.1 \%$ SDS, $1 \%$ Triton $\mathrm{X}-100$, and $500 \mathrm{mM} \mathrm{NaCl}$ ), WB III (1 mM EDTA, 10 mM Tris-HCl (pH 8.1), 1\% NP-40, $1 \%$ deoxycholate, and $0.25 \mathrm{M} \mathrm{LiCl}$ ), and then twice with $1 \mathrm{mM}$ EDTA and $10 \mathrm{mM}$ Tris- $\mathrm{HCl}$ ( $\mathrm{pH} 8.1$ ). Precipitated complexes were removed from the beads through three sequential incubations of $10 \mathrm{~min}$ with $50 \mu \mathrm{l}$ of $1 \% \mathrm{SDS}$ and $0.1 \mathrm{M} \mathrm{NaHCO}_{3}$. Cross-linking was then reversed by an overnight incubation at $65^{\circ} \mathrm{C}$. DNA was purified with Qiaquick columns (Qiagen). Subsequent quantitative PCRs analysis used $1 \mu \mathrm{l}$ of input material and $5 \mu \mathrm{l}$ of chromatin immunoprecipitation (ChIP) samples and were performed on a BioRad MyiQ apparatus using Bio-Rad iQ SYBR Green supermix. The sequences of the oligonucleotides used, 
designed using Primer3 (http://frodo.wi.mit.edu/cgibin/primer3/primer3_www.cgi), are: CAR (left 5'-CCTCTCGCGCTTTTTATGTC-3'; right $5^{\prime}$-TCTCTGACCTCATGCTCACG-3'), $p S 2 / T F F 1$ (left $5^{\prime}$-TCATCTTGGCTGAGGGATCT- $3^{\prime}$; right $5^{\prime}$-TTCCGGCCATCTCTCACTAT-3'), RplpO (left $5^{\prime}$-ATCTAACTAGCACACGAACCTT- $3^{\prime}$; right $5^{\prime}$-CTGTATTCGTTCAGCTTTGTCT $-3^{\prime}$ ). The PCR efficiency was calculated for each oligonucleotide set, using serial dilutions of inputs. Once normalized to inputs following the $\Delta \mathrm{Ct}$ method, the results were normalized again to the ChIP performed using the control anti-HA antibody.

\section{Proliferation assay}

MCF-7 cells that had been stably transfected with a CMV-LUC reporter were grown in 24-well plates in the presence of $10^{-9} \mathrm{M} \mathrm{E}_{2}$ for 4-days, and in the presence of $20 \mu \mathrm{l}$ of whole mouse serum or E1-1 antiCAR hybridoma supernatant (Hemmi et al. 1998). Cells were then collected and luciferase activity was measured. Concerning wild-type MCF-7, MCF-7$C A R$, MDA-MB-231, and MDA-MB-231-CAR, their proliferation was quantified by counting the cells on a cell counter.

\section{Results}

\section{$E_{2}$ increases the transduction of ER-positive breast cancer cells by adenovirus}

The role and the regulation of $C A R$ expression in breast cancer cells remain elusive. We hypothesized that estrogens, which regulate the growth of ER-positive breast cancer cells, could modify their sensitivity to adenoviral infection, through a regulation of $C A R$ levels. To analyze whether estrogens could modify the adenoviral transduction, we pre-treated ER-positive breast cancer cells MCF-7 with $\mathrm{E}_{2}$ for $24 \mathrm{~h}$ before infecting them with an adenovirus encoding $\beta$-galactosidase (Ad-GAL) at increasing MOIs. We observed that adenoviral transduction was strongly enhanced in $\mathrm{E}_{2}$-treated cells compared with control cells (Fig. 1A), which suggests that $\mathrm{E}_{2}$ modifies the expression of a factor involved in adenoviral transduction. Microscopic observation confirmed that the increased staining of the plates was the result of a higher number of infected cells (Fig. 1B). On the other hand, ER-negative MDA-MB-231 cells were similarly infected by the virus in the absence or the presence of $E_{2}$, demonstrating that $E R$ was required for $E_{2}$ regulation of adenoviral transduction (Fig. 1C).
A
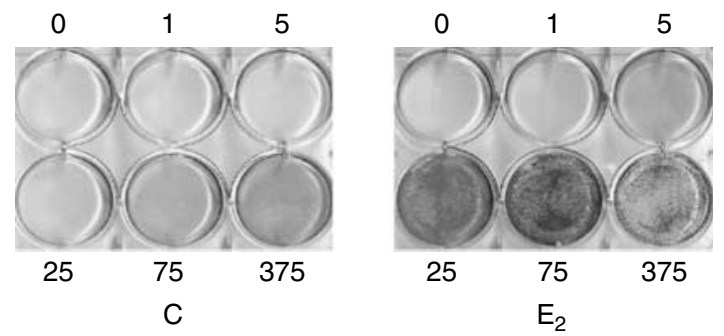

B

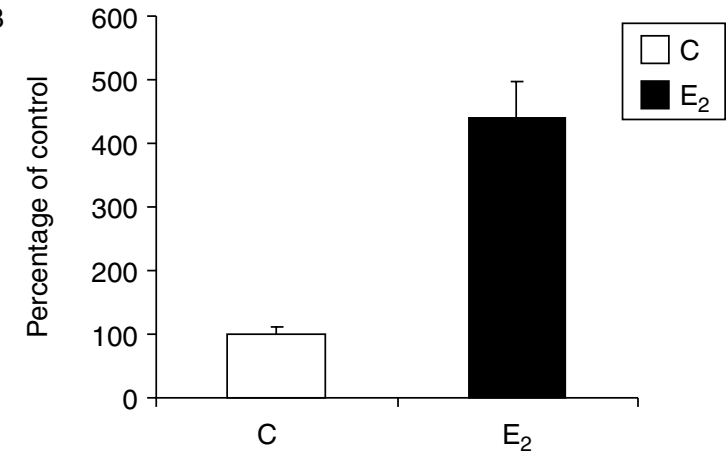

C

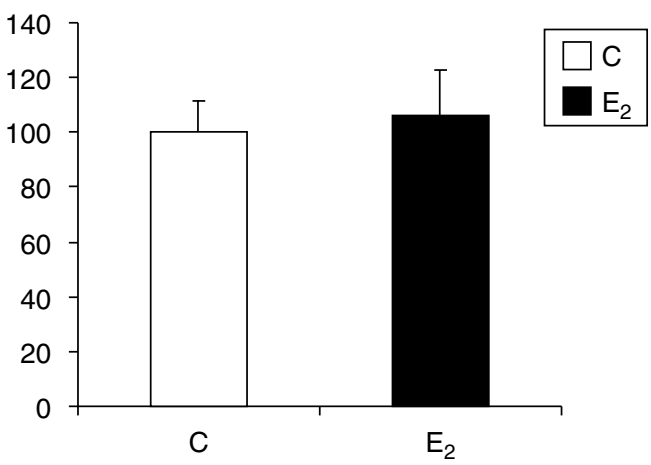

Figure 1 Estradiol increases adenovirus transduction.

(A) ER-positive breast cancer cells, MCF-7 cells, were treated for $24 \mathrm{~h}$ with ethanol vehicle $(\mathrm{C})$ or estradiol $\left(\mathrm{E}_{2} ; 1^{-9} \mathrm{M}\right)$ before infection with Ad-GAL virus at increasing multiplicity of infection $(\mathrm{MOI}=0,1,5,25,75,375)$. The infected cells were then grown for $48 \mathrm{~h}$ with ethanol vehicle or estradiol $\left(10^{-9} \mathrm{M}\right)$ and stained for $\beta$-gal activity as described in 'Materials and methods'.

(B) MCF-7 cells infected with adenovirus at $\mathrm{MOI}=1$ and treated with or without $E_{2}$. Quantification of $\beta$-gal-positive cells after adenovirus infection. $\beta$-gal-positive cells were counted from two non-overlapping fields. Results represent the mean \pm s.D. of three independent experiments and are expressed as the percentage of control cells. (C) ER $\alpha$-negative MDA-MB-231 cells were infected with adenovirus under the same conditions as in B. Results represent the quantification of $\beta$-gal-positive cells after adenovirus infection $(n=3)$.

\section{CAR levels are up-regulated by $\mathrm{E}_{2}$}

As $C A R$ is the main determinant of adenovirus infection, we hypothesized that its expression could be regulated by estrogens, which in turn explains the effects of $E_{2}$ on adenoviral transduction. To determine whether $\mathrm{E}_{2}$ was modulating CAR RNA levels, we treated MCF-7 cells at different times with $\mathrm{E}_{2}$. 
We measured the levels of transmembrane $C A R$ isoform (see Materials and methods) by real-time PCR. We observed that CAR RNA expression was induced at $8 \mathrm{~h}$ of $\mathrm{E}_{2}$ treatment and returned to basal levels after $24 \mathrm{~h}$ (Fig. 2A). To ensure that the regulation of $C A R$ RNA levels by $\mathrm{E}_{2}$ were mediated by the ER, MCF-7 cells were cotreated for $8 \mathrm{~h}$ with $\mathrm{E}_{2}$ and the pure anti-estrogen $\mathrm{ICI}_{182} 780$, which could strongly reduce CAR RNA induction by $\mathrm{E}_{2}$ (Fig. 2A). $C A R$ levels were also induced in another ER-positive breast cancer cell line, CAMA-1, suggesting that this was not specific of MCF-7 cells (data not shown). In addition, $C A R$ protein levels were also increased upon $\mathrm{E}_{2}$ treatment, as shown by western blot, but this induction by $\mathrm{E}_{2}$ returned to basal levels only at $48 \mathrm{~h}$ (Fig. 2B). We performed the same analysis in the ER-negative breast cancer cell line MDA-MB-231 (Fig. 2C) and observed

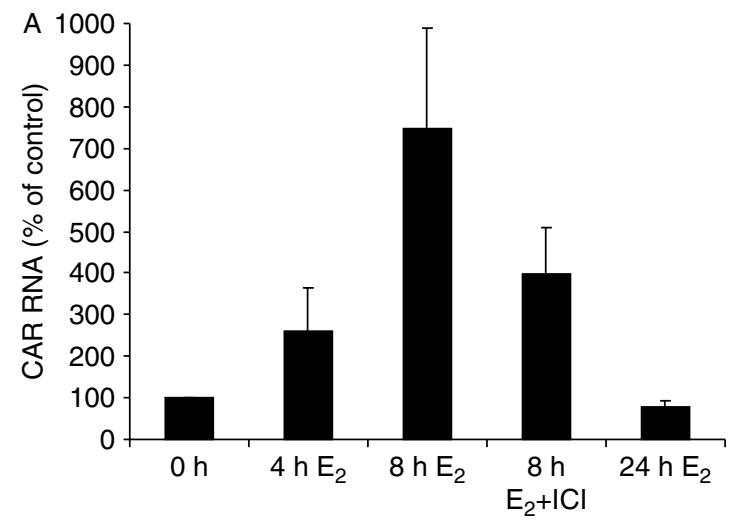

B

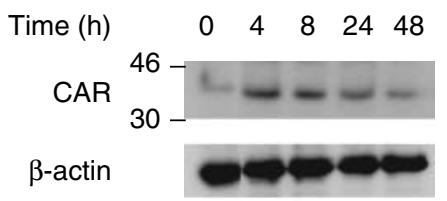

C

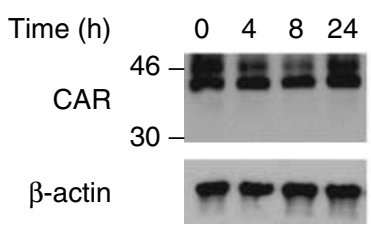

Figure $2 C A R$ expression is induced by $E_{2}$. (A) MCF-7 cells were treated with control vehicle ethanol, $E_{2}\left(10^{-9} M\right)$ for 8 or $24 \mathrm{~h}$ or with $\mathrm{E}_{2}+\mathrm{ICl}_{182780}\left(\mathrm{ICl} ; 10^{-6} \mathrm{M}\right)$ for $8 \mathrm{~h}$. CAR RNA levels were determined by real-time PCR. Results represent the mean of three independent experiments and are expressed as the percentage of control cells. (B) The levels of CAR protein were measured by western blot with $C A R$ antibody using extracts from MCF-7 cells treated with $E_{2}\left(10^{-9} M\right)$ for 4 , 8, or $24 \mathrm{~h}$. $\beta$-actin levels were detected to demonstrate equal loading. (C) Same experiment as in $B$, but in MDA-MB-231 cells. that $C A R$ protein levels were not significantly affected by $\mathrm{E}_{2}$ in these cells. This further demonstrates that ER is necessary for $C A R$ induction by $\mathrm{E}_{2}$.

\section{$C A R$ gene promoter is regulated by estrogens}

Next, we investigated the possible regulation of $C A R$ gene promoters by estrogens in MCF-7 cells. The transfection of $C A R$ promoter reporter gene construct showed that it was induced 1.8 -fold by $\mathrm{E}_{2}$ in MCF-7 cells (Fig. 3A). On the contrary, in the ER-negative breast cancer cell MDA-MB-231, the CAR promoter was not induced by $\mathrm{E}_{2}$ (Fig. $3 \mathrm{~B}$ ), demonstrating that $C A R$ is required for the regulation of $C A R$ promoter by estrogens. We performed a computer analysis of the $C A R$ promoter, and we identified four half-ERE (ER binding site) and one putative ERE (-571/-557) based on the consensus ERE sequence (Gruber et al. 2004, O'Lone et al. 2004; Fig. 4A). We used first deletion constructs of the CAR promoter (Fig. 4B). pGL3-522 $(-648 /-127)$ construct retained $E_{2}$ inducibility, but the further deletion of 94 bp (pGL3-428, -554/-127) by removing the putative ERE was sufficient to lose the responsiveness to $E_{2}$ (Fig. $4 \mathrm{~B}$ ). Using a point mutation construct of the ERE, we observed a strong reduction of $C A R$ promoter induction by $\mathrm{E}_{2}$ as well (Fig. 4B), reinforcing the central role of this ERE sequence in modulating $C A R$ promoter activity. To validate the functionality of CAR ERE, we performed ChIPs experiments. These experiments were performed in MCF-7 cells, which exhibit an estrogenic stimulation of $C A R$ and pS2/TFF1 genes (Fig. 4C). ChIPs showed an early recruitment of $\mathrm{ER} \alpha$ to $C A R$ ERE sequence in $30 \mathrm{~min}$ (Fig. 4D). The kinetic of recruitment of ER $\alpha$ to $C A R$ promoter was more rapid than the one observed for the $p S 2 / T F F 1$ promoter, which is also in agreement with the distinct kinetics of estrogen regulation of $C A R$ and $p S 2 / T F F 1$ mRNA (Fig. 4C, D). Finally, the ability of $\mathrm{ER} \alpha$ to bind to CAR ERE sequence was also confirmed by gel shift assays (data not shown).

\section{$C A R$ is involved in breast cancer proliferation}

As $C A R$ expression is regulated by estrogens, we next hypothesized that $C A R$ could be involved in the proliferation of ER-positive cells. MCF-7 cells were cultured in the presence of estrogen and treated either with control serum or anti-CAR antibody. Results showed that $C A R$ antibody reduced half the proliferation of cancer cells in the presence of $\mathrm{E}_{2}$ (Fig. 5A), which suggests that upregulation of $C A R$ by estrogen is an important step in the control of estrogen-dependent growth of ER-positive breast cancer cells. In the absence of $\mathrm{E}_{2}$, the $C A R$ antibody did not significantly 
A
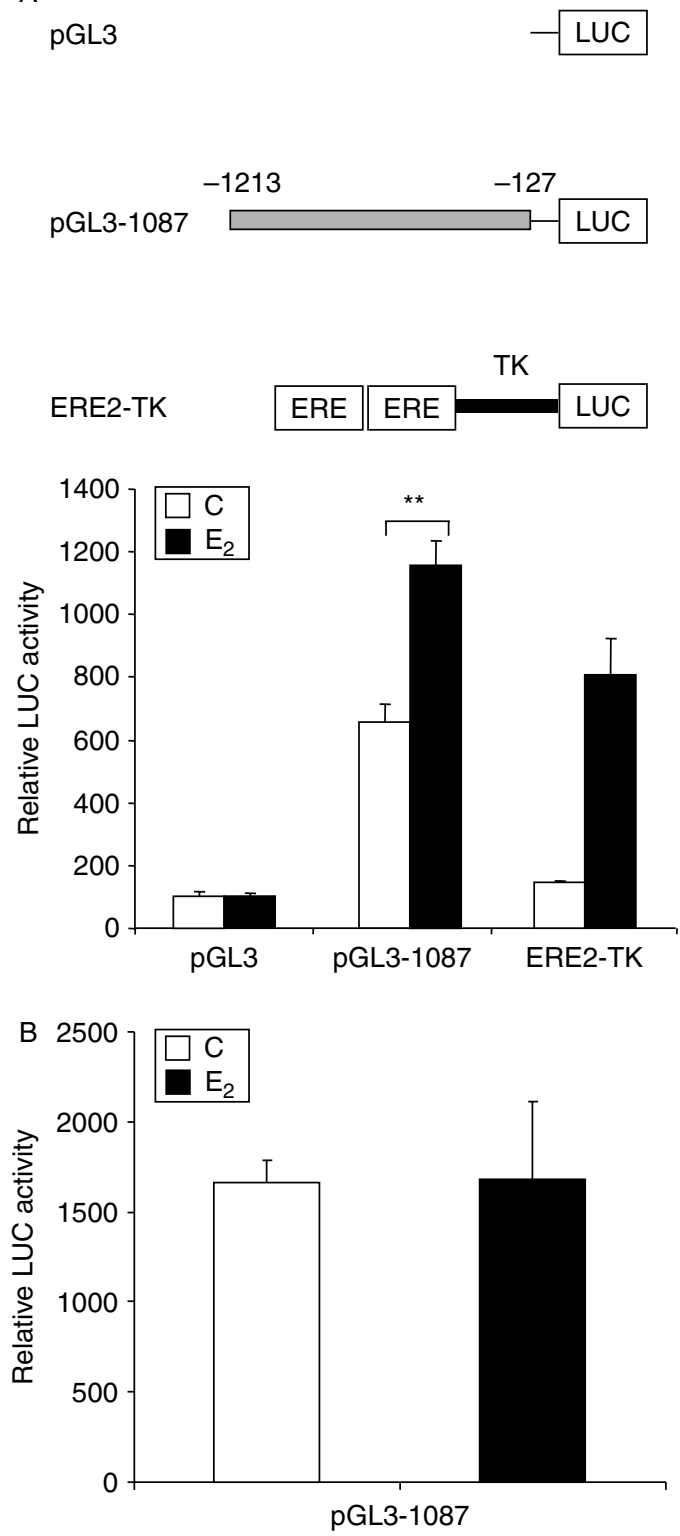

Figure $3 C A R$ promoter activity is enhanced by $\mathrm{E}_{2}$ in ER-positive breast cancer cells. (A) MCF-7 cells were transfected with pGL3, pGL3-1087, or ERE2-TK constructs, along with CMV-GAL as a control for transfection efficiency. Cells were grown in the presence or the absence of $E_{2}\left(10^{-9} \mathrm{M}\right)$. Results show relative luciferase activities (\% of values of $p G L 3$ vector without $E_{2}$ ) after normalization with $\beta$-gal activity (three independent experiments). ${ }^{\star \star} P<0.001$ using Student's $t$-test. (B) MDA-MB-231 cells were transfected with a pGL3-1087 construct, along with CMV-GAL, as a control for transfection efficiency. Cells were grown in the presence or the absence of $E_{2}\left(10^{-9} M\right)$. Results show relative luciferase activities after normalization with $\beta$-gal activity (three independent experiments).

alter cell proliferation. We used a second approach based on siRNA to demonstrate the role of $C A R$ in MCF-7 cell proliferation. Transfection of a siRNA against $C A R$ inhibited the induction of proliferation of
MCF-7 cells by $\mathrm{E}_{2}$ (Fig. 5B). To further confirm the potential role of $C A R$ in breast cancer cell proliferation, we generated a pool of stable transfectant MCF-7 cells for $C A R$ (Fig. 5C). When comparing the MCF-7-CAR cells to wild-type MCF-7 cells, we observed that MCF7-CAR cells displayed a higher proliferation rate compared with wild-type MCF-7 cells, in the absence and the presence of $\mathrm{E}_{2}$ (Fig. 5D). Of particular note, MCF-7-CAR cells grown in the absence of $\mathrm{E}_{2}$ had a similar proliferation as wild-type MCF-7 in the presence of $\mathrm{E}_{2}$. This data confirms that $C A R$ can enhance the proliferation of breast cancer cells. To demonstrate that $C A R$ effects were not specific to a single cell line, we also generated a $C A R$ stable transfectant in MDA-MB-231 cells (Fig. 5E). MDAMB-231-CAR also displayed an enhanced proliferation compared with wild-type cells (Fig. 5F), reinforcing the fact that $C A R$ stimulates breast cancer cell proliferation.

\section{Discussion}

Recent studies have highlighted the possible role of $C A R$ in carcinogenesis. However, it remains unclear whether $C A R$ levels are modified in breast cancer cells, and what the signals controlling its expression in such cells are. In this report, we have addressed the role of $C A R$ in breast cancer and its regulation by estrogens.

Although most of the studies have shown that $C A R$ levels were decreased in the aggressive forms of several cancers, including glioma and bladder cancer (Okegawa et al. 2001, Kim et al. 2003), the breast cancer situation seems to be different. Indeed, it was shown that $C A R$ levels were elevated in breast cancer tissues (Martin et al. 2005). Bruning et al. 2005 also observed in a murine model of breast cancer that $C A R$ expression was upregulated in carcinoma compared with pre-neoplastic lesion. To date, the role of $C A R$ in breast cancer and the factors regulating $C A R$ expression are poorly understood. Previous studies have shown that treatment of cancer cells with histone deacetylase inhibitors upregulates $C A R$ expression (Kitazono et al. 2001, Hemminki et al. 2003, Pong et al. 2003, Okegawa et al. 2007). Other signals such as the MAPK pathway, the action of glucocorticoids, tumour necrosis factor $\alpha$, and transforming growth factor- $\beta$ also modulate $C A R$ expression (Anders et al. 2003, Bruning \& Runnebaum 2003). Pong et al. 2006 have also reported an induction of CAR expression by the phytoestrogen genistein in bladder cells, but it remains unclear whether this occurs through ER.

$C A R$ levels are one of the primary determinants of adenoviral transduction. In this study, we show that $\mathrm{E}_{2}$ 
A

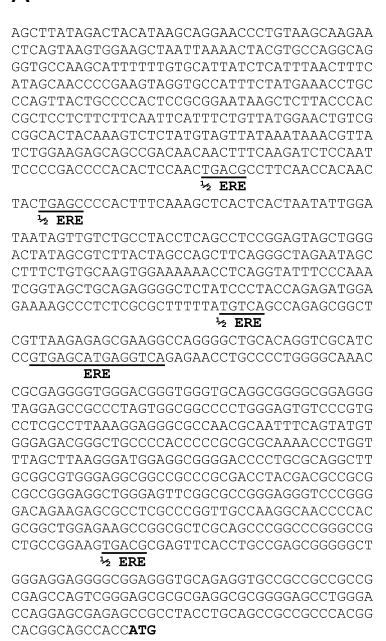

C
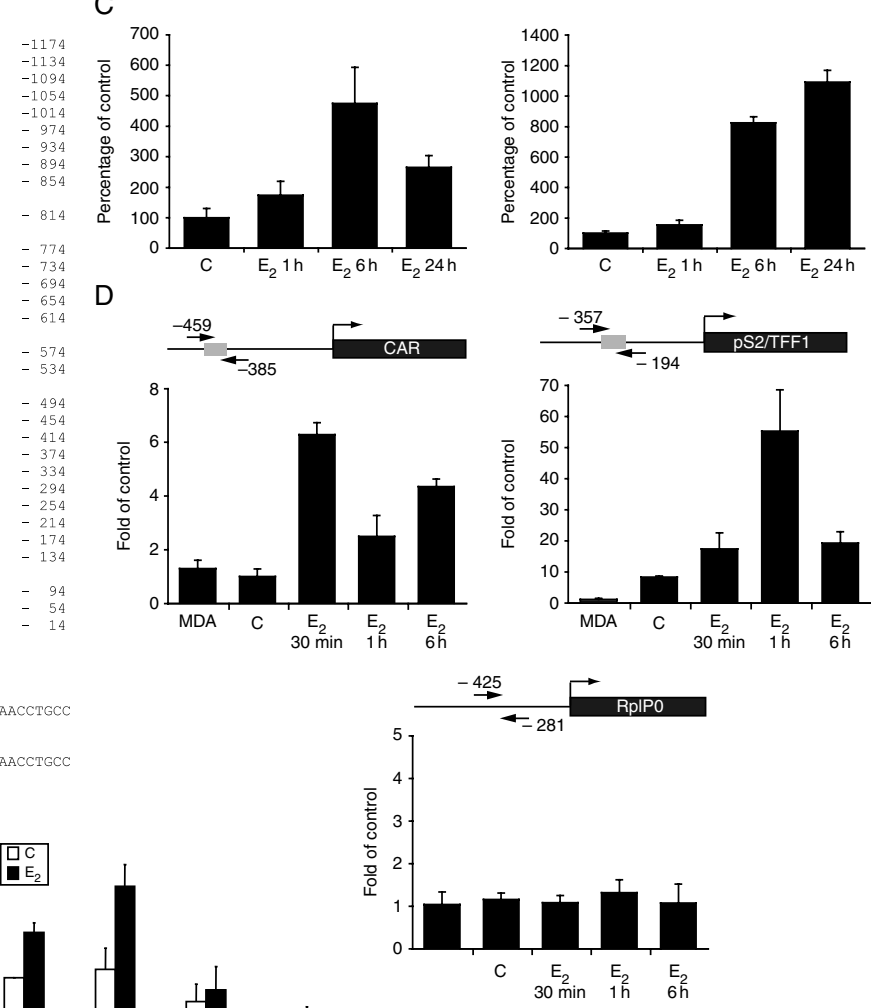

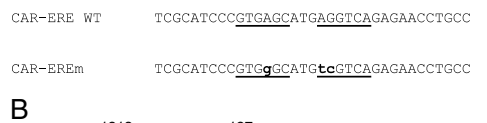

B
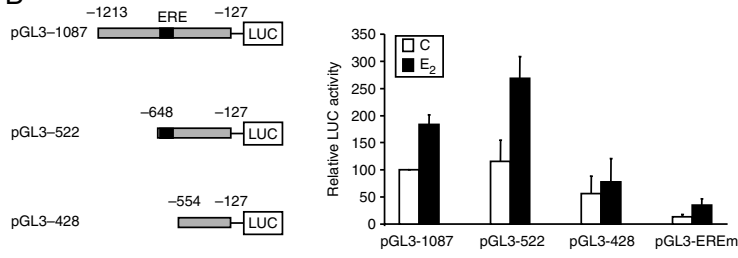

PGL3-EREm

Figure 4 Identification of an ERE in CAR promoter. (A) Sequence of $C A R$ promoters with the presence of half-ERE sites and an ERE sequence (TGAGCatgAGGTCA). The sequences of CAR-EREWT and CAR-EREm (mutant) oligonucleotides used in gel shift experiments are indicated at the bottom of the figure. (B) MCF-7 cells were transfected with pGL3-1087, pGL3-522, pGL3-428, or pGL3-EREm constructs along with CMV-GAL as a control for transfection efficiency. Cells were grown in the presence or the absence of $E_{2}\left(10^{-9} \mathrm{M}\right)$. Results show relative luciferase activities (\% of values of pGL3 basic vector without $\left.E_{2}\right)$ after normalization with $\beta$-gal activity (three independent experiments). (C) MCF-7 cells were treated with control vehicle ethanol (C) or $E_{2}\left(10^{-9} M^{2}\right.$ for different times. CAR (left graph) and pS2/TFF1 (right) mRNA levels were determined by real-time PCR. Results represent the mean of three independent experiments and are expressed as \% of controls (C). (D) Chromatin was prepared from MCF-7 cells treated as in RT-PCR experiments, or from ER-negative MDA-MB-231 cells (MDA), which were used as a control for specific immunoprecipitation. ChIP assays were then performed using antibodies directed against ER or the epitope $\mathrm{HA}$ as an additional control. Specific enrichment of CAR, pS2/TFF1, and control Rp/p0 promoter regions in anti-ER Chip-ped material was then evaluated by quantitative PCR, with values normalized to those obtained in samples immunoprecipitated using the control antibody (C). The regions amplified are illustrated within the schemes above each graph. Results represent the mean of three independent experiments.

increases ER-positive breast cancer cell transduction by type 5 adenoviruses. We also observed that $C A R$ levels were increased by $E_{2}$ in ER-positive breast cancer cells, which is in agreement with a previous study, using the ER-positive breast cancer cell line T47-D (Auer et al. 2009). This regulation was dependent on ERs, as $\mathrm{E}_{2}$ had no effect on $C A R$ levels and promoter activity in ER $\alpha$-negative MDA-MB-231 breast cancer cells. CAR expression was induced both at the RNA and protein levels by $\mathrm{E}_{2}$. However, $C A R$ RNA induction by $\mathrm{E}_{2}$ was transient, whereas $C A R$ protein induction could last for more than $24 \mathrm{~h}$. This suggests that $C A R$ RNA and protein kinetics of regulation and stability are different. It is possible that $C A R$ protein stability is affected indirectly by $\mathrm{E}_{2}$ through the synthesis of factors controlling its turnover, which could explain the delayed induction of $C A R$ protein expression.

Based on the rapid increase of $C A R$ RNA levels, we thus speculated that the regulation of $C A R$ gene by estrogens could be the result of a direct transcriptional regulation. Transfection experiments showed that $C A R$ promoter was directly regulated by estrogens, through an ERE located in the first $600 \mathrm{bp}$ of $C A R$ gene promoter as shown by transfection, ChIPs, and gel shift experiments. The ERE sequence found in $C A R$ 
promoter was a palindrome non-consensus sequence with a 3 bp spacing, which is the most common situation found in genes regulated by estrogen (Gruber et al. 2004, O'Lone et al. 2004).

Estrogens are known to be potent mitogen signals for ER-positive breast cancer cells (Prall et al. 1998), which could also potentially involve adhesion molecules such as $C A R$. It was previously shown that estrogen can modulate the expression of other adhesion

A
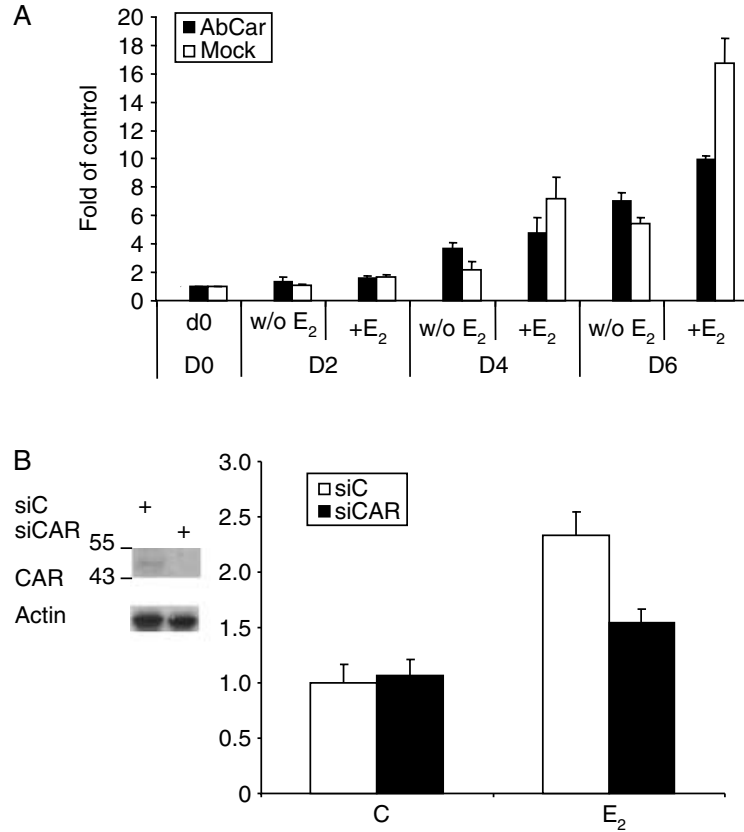

C

E

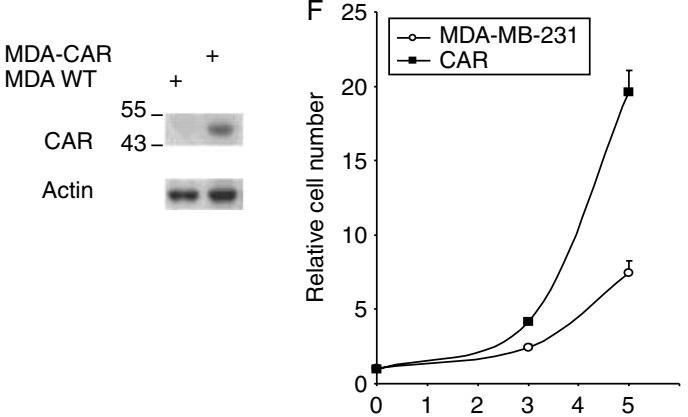

molecule such as $N$-cadherin, which is upregulated by $\mathrm{E}_{2}$ (MacCalman et al. 1995), or E-cadherin that is downregulated by $\mathrm{E}_{2}$ (Oesterreich et al. 2003). These molecules might directly or indirectly modulate cell proliferation, notably through cell architecture reorganization.

The possible role of $C A R$ in cancer cell proliferation remains controversial. Most studies have shown in bladder, cervical, ovary cancers, and glioma that $C A R$ was repressing cell proliferation (Okegawa et al. 2001, Kim et al. 2003, Bruning \& Runnebaum 2004, Huang et al. 2005, Wang et al. 2005, Zhang et al. 2007), whereas others have shown mitogenic properties for $C A R$ in lung cancer (Qin et al. 2004, Veena et al. 2009). The situation in breast cancer might be unique compared with other cancers. Indeed, it was shown that $C A R$ antagonizes the action of apoptosis inducing agents and in turn increases breast cancer cell survival (Bruning et al. 2005). In a similar manner, as for lung cancer in which $C A R$ silencing reduces tumor growth (Veena et al. 2009), we show that $C A R$ antibodies or CAR siRNA inhibit the estrogendependent growth of MCF-7 cells. We did not observe any sign of mortality when cells were treated with the $C A R$ antibody, which suggests that $C A R$ affects mainly cell proliferation than survival. In addition, we report that stable expression of CAR in MCF-7 cells

Figure $5 C A R$ enhances breast cancer cell proliferation. (A) MCF-7 cells were grown in DMEM-F12 supplemented with CD-FCS without (w/o $\mathrm{E}_{2}$ ), or with $10^{-9} \mathrm{M} \mathrm{E}_{2}\left(+\mathrm{E}_{2}\right)$, and incubated with pre-immune serum (mock), or $C A R$ antibody $(C A R \mathrm{Ab})$. Cells stably expressing luciferase reporters were lysed at days 2, 4, and 6 and subjected to luciferase activity. Results are expressed as fold of control cells grown in the absence of estradiol at day 0 , and in the absence of mouse pre-immune serum and data represent the mean \pm s.D. from triplicates. (B) MCF-7 cells were transfected with non-targeting siRNA ( $\mathrm{siC}$ ), or with CAR siRNA (siCAR), and treated with $10^{-9} \mathrm{M} \mathrm{E}_{2}\left(+\mathrm{E}_{2}\right)$. Left panel: measure of $C A R$ and protein levels in transfected cells by western blot at day 3 . $\beta$-Actin levels were detected to demonstrate equal loading. Right panel: proliferation was measured at day 3 after transfection, and results are expressed as fold of control cells grown in the absence of estradiol at day 0 . Data represent the mean \pm S.D. from triplicates. (C) Characterization of the pool of MCF-7-CAR stable transfectants by western blot. $\beta$-actin levels were detected to demonstrate equal loading. (D) Wild-type MCF-7 cells or MCF-7-CAR cells (CAR) were grown in DMEM-F12 supplemented with CD-FCS without or with $10^{-9} \mathrm{M} \mathrm{E}_{2}\left(+\mathrm{E}_{2}\right)$. Proliferation rate is expressed as fold of control cells grown in the absence of estradiol at day 0 . The data represents the mean \pm S.D. from triplicates. (E) Characterization of the pool of MDA-MB-231-CAR stable transfectants by western blot. $\beta$-actin levels were detected to demonstrate equal loading. $(F)$ Wildtype MDA-MB-231 cells or MDA-MB-231-CAR cells (CAR) were grown in DMEM-F12 supplemented with FCS. Proliferation is expressed as fold of control cells grown at day 0 . Data represent the mean \pm s.D. from triplicates. 
enhances both the basal and the estrogen-induced proliferation of these cells. This observation suggests that $C A R$ could confer a hormone-independent growth to ER-positive breast cancer cells. Moreover, $C A R$ can also increase the proliferation of ER $\alpha$-negative MDAMB-231 cells, suggesting that CAR could affect different types of breast cancer cells in a similar manner. The mechanisms underlying $C A R$ effects on proliferation in breast cancer cells remain to be investigated. We believe that cell-specific factors present in breast cancer cells, and not in cancer cells of other origins, might explain why $C A R$ stimulates the proliferation in breast cancer cells, whereas it represses the proliferation in other cancers.

The effects of $C A R$ on proliferation, which is mainly described as an adhesion molecule, might not be direct in breast cancer cells. CAR is a major component of TJs, as are other molecules such as occludin, claudin, tricellulin, and junction adhesion molecules (JAMs; Coyne \& Bergelson 2005). In polarized epithelial cells, $C A R$ is detected at the apical pole of the lateral membrane, where it colocalizes with the TJ protein zonula occludens-1 (ZO-1; Cohen et al. 2001). Recent reports suggest that TJs could regulate cell proliferation (Tsukita et al. 2008). TJs contain aqueous pores or channels that regulate paracellular permeability and serve to divide the apical and basolateral membrane compartments. As a component of TJs, CAR could affect ionic or $\mathrm{pH}$ conditions around epithelial cells and in turn modulates cell proliferation (Tsukita et al. 2008). Another hypothesis is that altering the features of cell adhesion by $C A R$ could modify cell signaling and interaction with other cofactors that directly control the proliferation or cell architecture. Increasing evidence suggest that TJs regulate gene expression (Balda \& Matter 2009). It has been shown that the cytoplasmic plaque associated with TJs is formed by multiple adaptors, scaffold proteins, and signaling components such as GTP-binding proteins, protein kinases, and phosphatases. These proteins can in turn modulate the expression or the activity of downstream signaling molecules such as cyclins, Jun/fos, or c-myc, which are known to regulate cell cycle (Balda \& Matter 2009). In particular, it might be possible that $C A R$ could indirectly affect phosphorylation levels of ER, which is a known mechanism for hormone-independent proliferation of ER-positive breast cancer cells. Cell context might explain the opposite effects of $C A R$ in breast cancer cells compared with other types of cancers. We cannot exclude the possibility that the presence of ER in breast cancer cells could enable a different network of factors susceptible to act in coordination with $C A R$ to elicit cell proliferation.
These results, together with the up-regulation of $C A R$ by $\mathrm{E}_{2}$, suggest that $C A R$ could be one of the early events leading to the induced proliferation of breast cancer cells. Our data could open the road for novel strategies to target ER-positive breast cancers.

\section{Declaration of interest}

There is no conflict of interest that could be perceived as prejudicing the impartiality of the research reported.

\section{Funding}

D V and L L C were the recipients of la Ligue contre le Cancer. P E was supported by ARTP. M B was supported by ARC. We are grateful to the Vector Core of the University Hospital of Nantes, supported by the Association Française contre les Myopathies (AFM) for the production of Adenoviruses. This work was supported by ARC.

\section{Acknowledgements}

We thank Dr S Hemmi for kindly providing the $C A R$ antibody and the $C A R$ expression vector. We thank Dr F Asadi for critical reading of the manuscript.

\section{References}

Anders M, Christian C, McMahon M, McCormick F \& Korn WM 2003 Inhibition of the Raf/MEK/ERK pathway up-regulates expression of the coxsackievirus and adenovirus receptor in cancer cells. Cancer Research 63 2088-2095.

Auer D, Reimer D, Porto V, Fleischer M, Roessler J, Wiedemair A, Marth C, Muller-Holzner E, Daxenbichler G \& Zeimet AG 2009 Expression of coxsackieadenovirus receptor is related to estrogen sensitivity in breast cancer. Breast Cancer Research and Treatment 116 103-111. (doi:10.1007/s10549-008-0108-0)

Balda MS \& Matter K 2009 Tight junctions and the regulation of gene expression. Biochimica et Biophysica Acta 1788 761-767. (doi:10.1016/j.bbamem.2008.11. 024)

Bardin A, Boulle N, Lazennec G, Vignon F \& Pujol P 2004 Loss of ERbeta expression as a common step in estrogendependent tumor progression. Endocrine-Related Cancer 11 537-551. (doi:10.1677/erc.1.00800)

Bergelson JM, Cunningham JA, Droguett G, Kurt-Jones EA, Krithivas A, Hong JS, Horwitz MS, Crowell RL \& Finberg RW 1997 Isolation of a common receptor for coxsackie B viruses and adenoviruses 2 and 5. Science 275 1320-1323. (doi:10.1126/science.275.5304.1320)

Bruning A \& Runnebaum IB 2003 CAR is a cell-cell adhesion protein in human cancer cells and is expressionally modulated by dexamethasone, TNFalpha, and TGFbeta. Gene Therapy 10 198-205. (doi:10.1038/sj.gt. 3301887) 
Bruning A \& Runnebaum IB 2004 The coxsackie adenovirus receptor inhibits cancer cell migration. Experimental Cell Research 298 624-631. (doi:10.1016/j.yexcr.2004.05.001)

Bruning A, Stickeler E, Diederich D, Walz L, Rohleder H, Friese K \& Runnebaum IB 2005 Coxsackie and adenovirus receptor promotes adenocarcinoma cell survival and is expressionally activated after transition from preneoplastic precursor lesions to invasive adenocarcinomas. Clinical Cancer Research 11 4316-4320. (doi:10.1158/1078-0432.CCR-04-2370)

Cheng J, Lee EJ, Madison LD \& Lazennec G 2004 Expression of estrogen receptor beta in prostate carcinoma cells inhibits invasion and proliferation and triggers apoptosis. FEBS Letters 566 169-172. (doi:10.1016/j. febslet.2004.04.025)

Cohen CJ, Gaetz J, Ohman T \& Bergelson JM 2001 Multiple regions within the coxsackievirus and adenovirus receptor cytoplasmic domain are required for basolateral sorting. Journal of Biological Chemistry 276 25392-25398. (doi:10.1074/jbc.M009531200)

Coyne CB \& Bergelson JM 2005 CAR : a virus receptor within the tight junction. Advanced Drug Delivery Reviews 57 869-882. (doi:10.1016/j.addr.2005.01.007)

Duong V, Licznar A, Margueron R, Boulle N, Busson M, Lacroix M, Katzenellenbogen BS, Cavailles V \& Lazennec G 2006 ERalpha and ERbeta expression and transcriptional activity are differentially regulated by HDAC inhibitors. Oncogene 25 1799-1806. (doi:10. 1038/sj.onc.1209102)

Glasgow JN, Everts M \& Curiel DT 2006 Transductional targeting of adenovirus vectors for gene therapy. Cancer Gene Therapy 13 830-844. (doi:10.1038/sj.cgt.7700928)

Gruber CJ, Gruber DM, Gruber IM, Wieser F \& Huber JC 2004 Anatomy of the estrogen response element. Trends in Endocrinology and Metabolism 15 73-78. (doi:10. 1016/j.tem.2004.01.008)

Haviv YS, Blackwell JL, Kanerva A, Nagi P, Krasnykh V, Dmitriev I, Wang M, Naito S, Lei X, Hemminki A et al. 2002 Adenoviral gene therapy for renal cancer requires retargeting to alternative cellular receptors. Cancer Research 62 4273-4281.

Hemmi S, Geertsen R, Mezzacasa A, Peter I \& Dummer R 1998 The presence of human coxsackievirus and adenovirus receptor is associated with efficient adenovirus-mediated transgene expression in human melanoma cell cultures. Human Gene Therapy 9 2363-2373. (doi:10. 1089/hum.1998.9.16-2363)

Hemminki A, Kanerva A, Liu B, Wang M, Alvarez RD, Siegal GP \& Curiel DT 2003 Modulation of coxsackieadenovirus receptor expression for increased adenoviral transgene expression. Cancer Research 63 847-853.

Henderson BE, Ross R \& Bernstein L 1988 Estrogens as a cause of human cancer. The Richard and Linda Rosenthal foundation award lecture. Cancer Research 48 246-253.

Huang KC, Altinoz M, Wosik K, Larochelle N, Koty Z, Zhu L, Holland PC \& Nalbantoglu J 2005 Impact of the coxsackie and adenovirus receptor (CAR) on glioma cell growth and invasion: requirement for the C-terminal domain. International Journal of Cancer 113 738-745. (doi:10.1002/ijc.20623)

Katzenellenbogen BS, Montano MM, Ediger TR, Sun J, Ekena K, Lazennec G, Martini PG, McInerney EM, Delage-Mourroux R, Weis K et al. 2000 Estrogen receptors: selective ligands, partners, and distinctive pharmacology. Recent Progress in Hormone Research 163-193; discussion 194-5.

Kim M, Sumerel LA, Belousova N, Lyons GR, Carey DE, Krasnykh V \& Douglas JT 2003 The coxsackievirus and adenovirus receptor acts as a tumour suppressor in malignant glioma cells. British Journal of Cancer $\mathbf{8 8}$ 1411-1416. (doi:10.1038/sj.bjc.6600932)

Kitazono M, Goldsmith ME, Aikou T, Bates S \& Fojo T 2001

Enhanced adenovirus transgene expression in malignant cells treated with the histone deacetylase inhibitor FR901228. Cancer Research 61 6328-6330.

Lazennec G 2006 Estrogen receptor beta, a possible tumor suppressor involved in ovarian carcinogenesis. Cancer Letters 231 151-157. (doi:10.1016/j.canlet.2005. 01.021)

Lazennec G, Kern L, Salbert G, Saligaut D \& Valotaire Y 1996 Cooperation between the human estrogen receptor (ER) and MCF-7 cell-specific transcription factors elicits high activity of an estrogen-inducible enhancer from the trout ER gene promoter. Molecular Endocrinology 10 1116-1126. (doi:10.1210/me.10.9.1116)

Lazennec G, Alcorn JL \& Katzenellenbogen BS 1999 Adenovirus-mediated delivery of a dominant negative estrogen receptor gene abrogates estrogen-stimulated gene expression and breast cancer cell proliferation. Molecular Endocrinology 13 969-980. (doi:10.1210/me. 13.6.969)

Lazennec G, Bresson D, Lucas A, Chauveau C \& Vignon F 2001 ERbeta inhibits proliferation and invasion of breast cancer cells. Endocrinology 142 4120-4130. (doi:10. 1210/en.142.9.4120)

Li Y, Pong RC, Bergelson JM, Hall MC, Sagalowsky AI, Tseng CP, Wang Z \& Hsieh JT 1999 Loss of adenoviral receptor expression in human bladder cancer cells: a potential impact on the efficacy of gene therapy. Cancer Research 59 325-330.

Lucas A, Kremer EJ, Hemmi S, Luis J, Vignon F \& Lazennec G 2003 Comparative transductions of breast cancer cells by three DNA viruses. Biochemical and Biophysical Research Communications 309 1011-1016. (doi:10.1016/ j.bbrc.2003.08.101)

MacCalman CD, Farookhi R \& Blaschuk OW 1995 Estradiol regulates $N$-cadherin mRNA levels in the mouse ovary. Developmental Genetics 16 20-24. (doi:10.1002/dvg. 1020160106)

Martin TA, Watkins G \& Jiang WG 2005 The coxsackieadenovirus receptor has elevated expression in human breast cancer. Clinical and Experimental Medicine 5 122-128. (doi:10.1007/s10238-005-0076-1) 
Matsumoto K, Shariat SF, Ayala GE, Rauen KA \& Lerner SP 2005 Loss of coxsackie and adenovirus receptor expression is associated with features of aggressive bladder cancer. Urology 66 441-446. (doi:10.1016/j. urology.2005.02.033)

Métivier R, Penot G, Hubner MR, Reid G, Brand H, Kos M \& Gannon F 2003 Estrogen receptor-alpha directs ordered, cyclical, and combinatorial recruitment of cofactors on a natural target promoter. Cell 115 751-763. (doi:10.1016/ S0092-8674(03)00934-6)

Oesterreich S, Deng W, Jiang S, Cui X, Ivanova M, Schiff R, Kang K, Hadsell DL, Behrens J \& Lee AV 2003 Estrogenmediated down-regulation of E-cadherin in breast cancer cells. Cancer Research 63 5203-5208.

Okegawa T, Li Y, Pong RC, Bergelson JM, Zhou J \& Hsieh JT 2000 The dual impact of coxsackie and adenovirus receptor expression on human prostate cancer gene therapy. Cancer Research 60 5031-5036.

Okegawa T, Pong RC, Li Y, Bergelson JM, Sagalowsky AI \& Hsieh JT 2001 The mechanism of the growth-inhibitory effect of coxsackie and adenovirus receptor (CAR) on human bladder cancer: a functional analysis of car protein structure. Cancer Research 61 6592-6600.

Okegawa T, Sayne JR, Nutahara K, Pong RC, Saboorian H, Kabbani W, Higashihara E \& Hsieh JT 2007 A histone deacetylase inhibitor enhances adenoviral infection of renal cancer cells. Journal of Urology 177 1148-1156. (doi:10.1016/j.juro.2006.10.034)

O’Lone R, Frith MC, Karlsson EK \& Hansen U 2004 Genomic targets of nuclear estrogen receptors. Molecular Endocrinology 18 1859-1875. (doi:10.1210/me.2003-0044)

Pong R-C, Lai Y-J, Chen H, Okegawa T, Frenkel E, Sagalowsky A \& Hsieh J-T 2003 Epigenetic regulation of coxsackie and adenovirus receptor (CAR) gene promoter in urogenital cancer cells. Cancer Research 63 8680-8686.

Pong RC, Roark R, Ou JY, Fan J, Stanfield J, Frenkel E, Sagalowsky A \& Hsieh JT 2006 Mechanism of increased coxsackie and adenovirus receptor gene expression and adenovirus uptake by phytoestrogen and histone deacetylase inhibitor in human bladder cancer cells and the potential clinical application. Cancer Research 66 8822-8828. (doi:10.1158/0008-5472.CAN-05-4672)

Prall OW, Rogan EM \& Sutherland RL 1998 Estrogen regulation of cell cycle progression in breast cancer cells. Journal of Steroid Biochemistry and Molecular Biology 65 169-174. (doi:10.1016/S0960-0760(98)00021-1)
Qin M, Escuadro B, Dohadwala M, Sharma S \& Batra RK 2004 A novel role for the coxsackie adenovirus receptor in mediating tumor formation by lung cancer cells. Cancer Research 64 6377-6380. (doi:10.1158/00085472.CAN-04-1490)

Sachs MD, Rauen KA, Ramamurthy M, Dodson JL, De Marzo AM, Putzi MJ, Schoenberg MP \& Rodriguez R 2002 Integrin alpha(v) and coxsackie adenovirus receptor expression in clinical bladder cancer. Urology 60 531-536. (doi:10.1016/S0090-4295(02)01748-X)

Santen R, Manni A, Harvey H \& Redmond C 1990 Endocrine treatment of breast cancer in women. Endocrine Reviews 11 221-265. (doi:10.1210/edrv-11-2-221)

Thoelen I, Magnusson C, Tagerud S, Polacek C, Lindberg M \& Van Ranst M 2001 Identification of alternative splice products encoded by the human coxsackie-adenovirus receptor gene. Biochemical and Biophysical Research Communications 287 216-222. (doi:10.1006/ bbrc.2001.5535)

Tsukita S, Yamazaki Y, Katsuno T, Tamura A \& Tsukita S 2008 Tight junction-based epithelial microenvironment and cell proliferation. Oncogene 27 6930-6938. (doi:10. 1038/onc.2008.344)

Veena MS, Qin M, Andersson A, Sharma S \& Batra RK 2009 CAR mediates efficient tumor engraftment of mesenchymal type lung cancer cells. Laboratory Investigation 89 875-886. (doi:10.1038/labinvest.2009.56)

Wang B, Chen G, Li F, Zhou J, Lu Y \& Ma D 2005 Inhibitory effect of coxsackie adenovirus receptor on invasion and metastasis phenotype of ovarian cancer cell line SKOV3. Journal of Huazhong University of Science and Technology. Medical Sciences 25 85-87, 93. (doi:10.1007/ BF02831395)

Zhang LL, He DL, Li X, Li L, Zhu GD, Zhang D \& Wang XY 2007 Overexpression of coxsackie and adenovirus receptor inhibit growth of human bladder cancer cell in vitro and in vivo. Acta Pharmacologica Sinica 28 895-900. (doi:10.1111/j.1745-7254.2007.00574.x)

Received in final form 21 February 2011

Accepted 9 March 2011

Made available online as an Accepted Preprint 9 March 2011 